Ann. Zootech., 1980, 29, nº h. s., 285-293.

\title{
Influence of feeding levels and weights at slaughtering on Chianina $\times$ Friesian performances*
}

\author{
A. ROMITA, A. BORGHESE, S. GIGLI and Diana VECCIA SCAVALLI \\ Sezione produzione carne, \\ Istituto Sperimentale per la Zootecnia, \\ Via Salaria 31, Monterotondo Scalo, Rome, Italy.
}

\begin{abstract}
On young Chianina $\mathrm{x}$ Friesian bulls, gain, feed conversion ratio, carcase composition and conformation, physical, chemical and organoleptic characteristics of meat as related to different feeding levels and weights at slaughtering, are investigated. Three feeding levels are considered : ad libitum $\mathrm{H}(100$ per cent $), \mathrm{M}(85$ per cent $)$ and $\mathrm{L}(75$ per cent $)$. At $60 \mathrm{~kg}$ before final weights were achieved, the animals in groups $M$ and $L$ were divided ; half of them continued to be fed on the same ration (MM and LL) whilst the other half were submitted to level $\mathrm{H}$ (MH and $\mathrm{LH})$.

The results can be summarised as follows :

Higher weight at slaughtering increases significantly feed conversion ratio (5.82 vs 5.45 ) and dressing percentage (64.41 vs 63.27 ) while it reduces slightly panel taste scores for tenderness, flavour and juiciness.

Higher energy supply affects daily gain. Fat deposition increases with feeding levels ; significant differences were found between group $\mathrm{H}$ and the other groups.

Generally chemical and physical characteristics of meat did not show significant differences.

In panel taste, significant but small differences were found at the various feeding levels.

The most suitable economical results were reached by heavier animals and by an intensive f'eeding level after a period of restriction.
\end{abstract}

\section{Résumé}

\section{Influence du niveau d'alimentation et du poids à l'abattage sur les performances de taurillons Chianina $x$ Frisons}

Sur les taurillons Chianina $x$ Frisons on a étudié la vitesse de croissance, l'efficacité alimentaire, la conformation et la composition des carcasses, les caractéristiques physiques, chimiques et organoleptiques des viandes, en fonction de différents niveaux d'alimentation et différents poids à l'abattage. Trois niveaux d'alimentation ont été retenus : ad libitum

* This work was supported by National Research Council Prog, Analiz. Incremento disponibilità Alim. Orig. Animale. 
H (100 p. 100), M (85 p. 100) et L (75 p. 100). A partir de $60 \mathrm{~kg}$ avant le poids final, la moitié des animaux des lots $\mathbf{M}$ et $\mathbf{I}$. ont été maintenus sur leur niveau antérieur (MM et $L L$ ) tandis que l'autre moitié était alimentée au niveau H. Les principaux résultats peuvent ainsi être résumés :

L'abattage à un poids élevé entraîne une augmentation significative du coût alimentaire par $\mathrm{kg}$ de gain $(5,82$ contre 5,45$)$, du rendement en carcasse $(64,41$ contre 63,27$)$ et une réduction légère des notes de qualités organoleptiques pour la tendreté, la flaveur et la jutosité.

L'accroissement du niveau énergétique, modifie le gain journalier et augmente la formation des dépôts adipeux. Le lot $\mathrm{H}$ est significativement différent des autres lots.

Généralement les caractéristiques physiques et chimiques de la viande n'ont pas été significativement modifiées. Dans les tests de dégustation des différences faibles, mais significatives, sont apparues en fonction des niveaux d'alimentation.

Les meilleurs résultats économiques ont été atteints par les animaux les plus lourds, recevant un niveau alimentaire élevé après une période de restriction.

\section{Introduction}

The Italian production of beef accounts for only 50 per cent of our needs. The continuous rise in calf cost, moreover, affects the ultimates meat price. For these reasons the enhancement of final weight in the animals is therefore one of the most important factors to be considered, not only for Italy but for other European countries. This point was stressed in the conclusions of the Padua Seminar. As a result, the importance of knowing more about growth, feed conversion, carcase conformation and composition as outlined by ANDERSEN (1975) must be emphasized.

The interrelationship between genetic types, feeding levels and weight at slaughtering (CARrol, 1976 ; ROHR and DaENICKE, 1978 ; GEAY, 1977 ; BeraNGER, 1978 and LANGHOLZ, 1978) is also a salient factor to investigate, especially on crossbreeds with the Friesian which represents about 80 per cent of all Italian cows.

Feeding levels must ensure that final carcase weights in the higher brackets have low quantities of fat (LANGHOLZ, 1978), marbling fat in particular. There should be no great changes in general meat characteristics according to Italian consumer requirements.

The aim of our research has been to investigate the interrelationship between feeding levels and different weights at slaughtering on growth, carcase composition and meat characteristics. The animals involved in this first study were Chianina $\mathrm{x}$ Friesian males, late maturing crossbreds that we consider to be capable of providing high weights at slaughtering. In previous works (BORGHESE et al. $1977,1978 a$ ) this genotype showed interesting performances in comparison with purebred Friesians and other crosses.

\section{Material and methods}

In our experiment we used 75 crossbred Chianina x Friesian. The animals started in the experiment at 7 days after birth and were weaned at $100 \mathrm{~kg}$ liveweight ; during this period the animals were fed $6 \mathrm{~kg}$ milk replacers (12 per cent concentration), hay and concentrates ad libitum. After weaning and up to $250 \mathrm{~kg}$, 
the animals were individually fed with $3 \mathrm{~kg}$ per day and a concentrate containing 15 per cent alfalfa hay. From $250 \mathrm{~kg}$ weight to slaughter, the animals were given $3 \mathrm{~kg}$ hay per day together with mixture containing 30 per cent wheat straw.

Up to $150 \mathrm{~kg}$ the animals all received the same quantity of feed ; thereafter they were subdivided into three groups according to the proposed ultimate slaughter weights for the experiment, viz : 500, 600 and $700 \mathrm{~kg}$ liveweight (Table 1). For each final weight 3 feeding levels were considered : ad libitum $\mathrm{H}$ (100 per cent), M (85 per cent) and L (70 per cent). When the animals had attained a weight of $60 \mathrm{~kg}$ less than their projected slaughter weights, those in groups $\mathrm{M}$ and $\mathrm{L}$ were divided into two groups - the first group (MM and LL) continuing on the same level as before while the second group (MH and LH) was given increased quantities of feed up to the level of $\mathrm{H}$.

TABLE 1

NUMBER OF ANIMALS IN DIFFERENT GROUPS

\begin{tabular}{ccccccc}
\hline & \multicolumn{7}{c}{ Feeding levels } \\
Slaughter weight, $\mathrm{kg}$ & H & MM & MH & LL & LH & Total \\
\hline 500 & $\frac{5}{5}$ & 5 & $\frac{5}{5}$ & $\frac{5}{5}$ & $\frac{5}{5}$ & 25 \\
600 & $\frac{5}{5}$ & 5 & $\frac{5}{5}$ & $\frac{5}{5}$ & $\frac{5}{5}$ & 25 \\
700 & 5 & & & & & 75 \\
Total & & & & & & \\
\hline
\end{tabular}

$\mathrm{H}=100 \%$

$\mathrm{M}=85 \%$

$I=70 \%$

After slaughter the right side carcases were evaluated according to EEC standards for conformation and fatness (DE BoER et al., 1974) and jointed into 7 regions according to Williams and BergStrom (1976). Thereafter the regions were dissected into lean, fat, bone and other tissues. Twenty muscles or muscular groups from all the carcases were individually weighed. Covering and intermuscular fat were weighed separately and 33 muscle samples were taken for chemical analysis. The 13 main muscles were analysed to determine physical and chemical parameters :

Tenderness : Warner Bratzler Shear and compression test with Instrom 1140 (BORGHESE et al., 1978b).

Panel taste: On L.D. (slice $1 \times 4.8 \mathrm{~cm}$ ) cooked in an open pan and S.T. cooked in a pressure cooker. A judgement scale from 1 to 9 was used.

Colour : Brightness, purity and reflectance with E.E.L. spectrophotometer.

Protein, fat and ash content.

The experiment is still in progress and some of the results so far concerning the various animal groups are outlined in Table 1. 


\section{Results}

Daily gain and feed conversion ratio (Table 2)

There are no significant differences in daily gain between the two weights at slaughter considered (50 and $600 \mathrm{~kg}$ ). The feed conversion ratio is significantly higher in the heavier animals for the different maintenance requirements due to the higher liveweight and considering that the gain is quite similar.

TABLE 2

PERFORMANCES DURING LIFE AND AFTER SLAUGHTERING

\begin{tabular}{|c|c|c|c|c|c|c|}
\hline & \multicolumn{2}{|c|}{ Between weights } & \multicolumn{4}{|c|}{ Among feeding levels } \\
\hline & $\begin{array}{l}500 \\
\mathrm{~kg}\end{array}$ & $\begin{array}{c}600 \\
\mathrm{~kg}\end{array}$ & $\mathrm{H}$ & MH & LL & LH \\
\hline $\begin{array}{r}\text { Daily gain, } \\
\text { kg }\end{array}$ & 1.127 & 1.122 & $1.170^{\mathrm{a}}$ & $1.124^{\mathrm{a}}$ & $1.056^{\mathrm{b}}$ & $1.132^{\mathrm{a}}$ \\
\hline $\begin{array}{c}\text { Conv. ratio, } \\
\text { UF }\end{array}$ & $5.45^{b}$ & $5.82^{\mathrm{a}}$ & 5.89 & 5.66 & 5.61 & 5.27 \\
\hline Dressing $\frac{q}{6}$ & $63.3^{b}$ & $64.4^{\mathrm{a}}$ & 64.1 & 64.0 & 63.7 & 63.5 \\
\hline Conformation & 8.2 & 8.7 & 8.9 & 8.6 & 8.2 & 8.0 \\
\hline $\begin{array}{l}\text { Fatness } \\
\frac{\%}{0} \frac{1}{2} \text { carcas }\end{array}$ & 6.0 & 6.3 & 6.7 & 6.1 & 5.8 & 5.9 \\
\hline Lean & 67.9 & 68.2 & 67.4 & 67.8 & 68.5 & 68.5 \\
\hline Bone & 18.8 & 18.7 & $17.8^{b}$ & $19.1^{\mathrm{a}}$ & $19.4^{\mathrm{a}}$ & $19.0^{\mathrm{a}}$ \\
\hline Other tissues & 1.2 & 1.1 & $0.9^{b}$ & $1.3^{a}$ & $1.3^{\mathrm{a}}$ & $1.1^{\mathrm{a}}$ \\
\hline $\begin{array}{r}\text { Subcutaneous } \\
\text { fat }\end{array}$ & 4.7 & 4.6 & $5.7^{a}$ & $4.4^{b}$ & $4.1^{\mathrm{b}}$ & $4.2^{b}$ \\
\hline $\begin{array}{r}\text { Intermuscular } \\
\text { fat }\end{array}$ & 7.4 & 7.3 & 8.1 & 7.5 & 6.6 & 7.1 \\
\hline Total fat & 12.1 & $11.9^{\circ}$ & $13.9^{\mathrm{a}}$ & $11.8^{b}$ & $10.7^{b}$ & $11 \cdot 3^{b}$ \\
\hline
\end{tabular}

Note: Different letters in the same line indicate significant differences

The highest daily gain can be noted in the group $\mathrm{H}$; however, only group LL is significantly lower $(\mathrm{P}=0.05)$.

During the last $60 \mathrm{~kg}$ of gain, the group $\mathrm{LH}$ that received greater amounts of feed after the initial stage, showed a compensatory growth, and, in fact, in this period LH animals had a daily gain of $1.401 \mathrm{~kg}$ (25 per cent more than for the previous period and 50 per cent more than animals in group LL). Futhermore, AlmQuist, (1971) found a compensatory growth when the animals passed to intensive feeding after a period of restricted diet.

Group $H$ had the highest significant feed conversion index $(P=0.1)$ in comparison with group $\mathrm{LH}$ in which the high daily gain in the last period of fattening reduced the conversion index due to the lower fat content in the gain. 


\section{Dressing percentage and carcase evaluation}

Dressing percentage is significant only in favour of the heaviest animals due to a lower incidence of fifth quarter (GEAY, 1978).

Among feeding levels the trend of the two different types of fat is similar and fat percentage decreases with decreasing feeding levels as found by SorENSEN (1972) and ANDERSEN, (1975), and therefore, group H shows the highest values (significantly different in total and subcutaneous fat). Nonetheless, group $H$ shows the lowest bone percentage $(P=0.05)$ according to ANDERSEN (1975) and GEAY et al. (1976).

The conformation scores are good in all groups. Carcase fatness can be considered very satisfactory according to Italian consumer demands. The lean on carcase is about 68 per cent and the high value confirms the good conformation judgement. There is also good correlation between fat percentage and fatness scores in carcase.

Lean : fat ratio increases with final weight $(500 \mathrm{~kg}=5.59 ; 600 \mathrm{~kg}=5.72)$, but the variations are only appreciable when considered between feeding levels (4.86 in group $\mathbf{H}$ and 6.41 in group LL). Lean : bone ratio is quite similar in all groups.

\section{Physical and organoleptic characteristics of meat}

\section{1) Tenderness}

Tenderness values (Instrom 1140) are reported in Table 3 for six muscles : caput longum tricipitis brachii (T.B) ; supraspinatus (S.S) ; gluteobiceps (G.B) ; semitendinosus (S.T) ; semimembranosus (S.M) and longissimus dorsi (L.D).

There are no significant differences within muscles for the two final weights considered but the heavier animals show a trend towards less tender meat according to Bouton et al. (1978) ; Borghese et al. (1978c).

With regard to feeding levels, group $\mathrm{H}$ shows highest values at Warner Bratzler Shear significant only in longissimus dorsi.

Obviously there are significant differences between different muscles; the most tender muscles, both for WBS and compression tests, are longissimus dorsi and caput longum tricipitis brachii.

\section{2) Panel taste}

The judges evaluation concluded that the $500 \mathrm{~kg}$ animals' meat characteristics were better than those of the $600 \mathrm{~kg}$ animals' with both types of cooking. This correlates with many authors, Prost et al. (1975) ; REAGAN et al. (1976); Borghese et al. $(1978 \mathrm{c})$.

Among feeding levels the MH group shows the most tender and savoury meat with two methods of cooking and the most juicy meat with pressure cooking. Overall, the meat cooked in pressure cookers was considered better for tenderness and flavour. 
TABLE 3

TENDERNESS VALUES AT INSTROM $1140 \quad(\mathrm{~kg})$

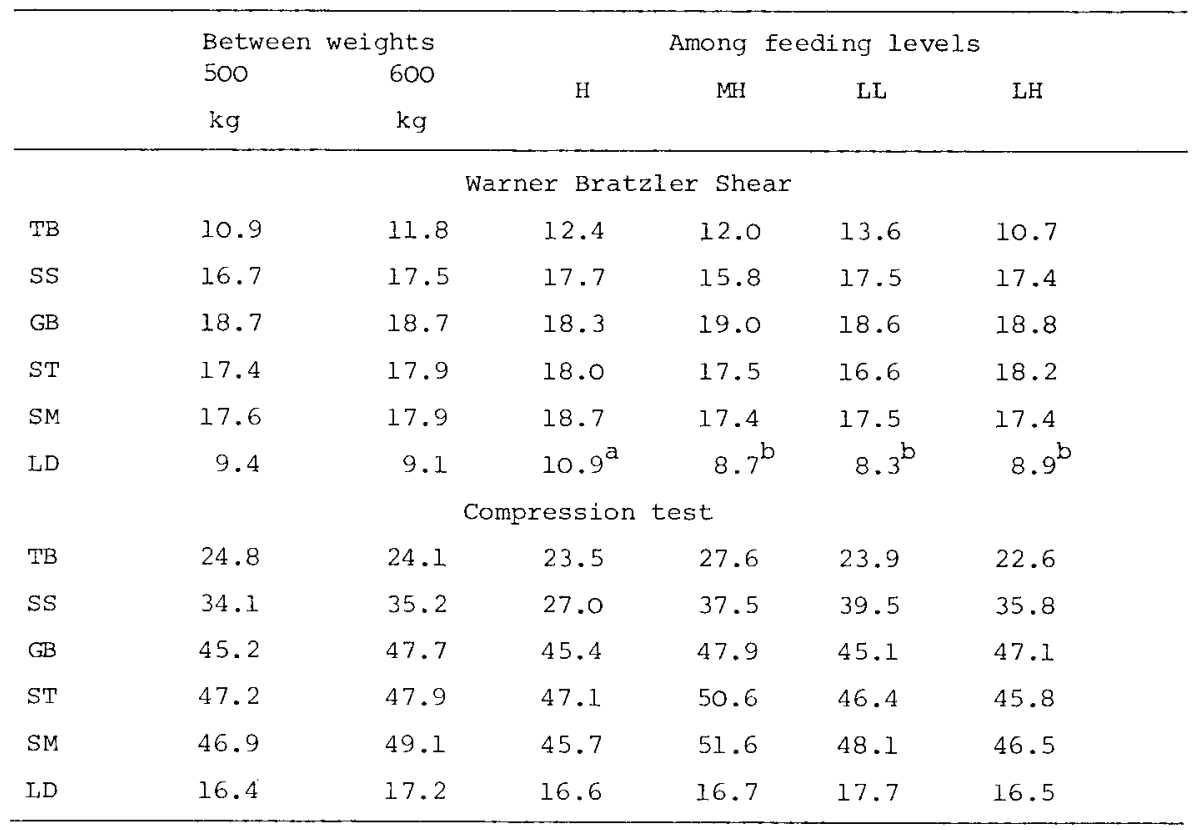

TABLE 4

PANEL TASTE SCORES

\begin{tabular}{|c|c|c|c|c|c|c|}
\hline & $\begin{array}{l}\text { Betwe } \\
500 \\
\mathrm{~kg}\end{array}$ & $\begin{array}{r}\text { ights } \\
600 \\
\mathrm{~kg}\end{array}$ & $\mathrm{H}$ & nong $f e$ & ng leve & $\mathrm{LH}$ \\
\hline \multicolumn{7}{|c|}{ Open pan } \\
\hline Tenderness & $7.0^{a}$ & $6.4^{b}$ & $6.6^{a b}$ & $6.9^{a}$ & $6.9^{\mathrm{a}}$ & $6.3^{\mathrm{b}}$ \\
\hline Flavour & $6.6^{\mathrm{a}}$ & $6.2^{\mathrm{b}}$ & $6.6^{\mathrm{a}}$ & $6.6^{\mathrm{a}}$ & $6.2^{\mathrm{b}}$ & $6.2^{\mathrm{b}}$ \\
\hline Juiciness & $6.5^{\mathrm{a}}$ & $6.1^{b}$ & $6.5^{\mathrm{a}}$ & $6.3^{\mathrm{ab}}$ & $6.3^{a b}$ & $6.0^{\mathrm{b}}$ \\
\hline \multicolumn{7}{|c|}{ Pressure cooking } \\
\hline Tenderness & $7.7^{\mathrm{a}}$ & $7.3^{b}$ & 7.4 & 7.7 & 7.3 & 7.6 \\
\hline Flavour & $7.0^{\mathrm{a}}$ & $6.7^{\mathrm{b}}$ & $6.9^{\mathrm{ab}}$ & $7.0^{\mathrm{a}}$ & $6.6^{b}$ & $6.9^{a b}$ \\
\hline Juiciness & 6.2 & 6.1 & $5.7 \mathrm{~b}$ & $6.8 \mathrm{a}$ & $6.0 \mathrm{ab}$ & $6.1 \mathrm{ab}$ \\
\hline
\end{tabular}




\section{3) Colour}

Neither of the parameters considered gave significant differences between final weights (Table 5). The only significant differences among feeding levels were found in group $\mathrm{H}$ for shoulder muscles, and, in fact, brightness is highest in S.S. and purity in T.B. The light muscles are semitendinosus and longissimus dorsi.

TABLE 5

COLOUR VALUES AT E.E.L SPECTROPHOTOMETER

\begin{tabular}{|c|c|c|c|c|c|c|}
\hline \multirow[b]{2}{*}{ Muscles } & \multicolumn{2}{|c|}{ Between weights } & \multicolumn{4}{|c|}{ Among feeding levels } \\
\hline & $\begin{array}{c}500 \\
\mathrm{~kg}\end{array}$ & $\begin{array}{l}600 \\
\mathrm{~kg}\end{array}$ & $\mathrm{H}$ & $\mathrm{MH}$ & LL & $\mathrm{LH}$ \\
\hline & \multicolumn{6}{|c|}{ Reflectance $\frac{\mathrm{q}}{5}(520 \mathrm{~nm})$} \\
\hline TB & 11.7 & 11.7 & 12.6 & 11.6 & 10.9 & 11.8 \\
\hline ss & 11.9 & 12.0 & 13.4 & 10.9 & 12.1 & 11.8 \\
\hline GB & 13.2 & 13.4 & 13.5 & 12.9 & 12.8 & 14.0 \\
\hline ST & 15.7 & 16.3 & 18.3 & 15.8 & 13.7 & 16.2 \\
\hline SM & 13.3 & 13.6 & 14.0 & 13.1 & 12.9 & 13.8 \\
\hline LD & 14.0 & 14.3 & 15.2 & 13.1 & 14.3 & 14.5 \\
\hline \multicolumn{7}{|c|}{ Brightness $\frac{\%}{6}$} \\
\hline $\mathrm{TB}$ & 14.0 & 14.5 & 15.9 & 13.9 & 13.5 & 14.0 \\
\hline SS & 14.5 & 14.5 & $16.4^{\mathrm{a}}$ & $13.3^{b}$ & $14.1^{\mathrm{b}}$ & $14.5^{\mathrm{b}}$ \\
\hline GB & 15.6 & 16.3 & 17.8 & 15.1 & 15.3 & 15.9 \\
\hline ST & 19.3 & 19.0 & 21.3 & 18.7 & 17.9 & 18.9 \\
\hline SM & 15.6 & 16.5 & 18.0 & 15.4 & 15.5 & 15.6 \\
\hline LD & 16.5 & 17.1 & 19.0 & 15.5 & 16.6 & 16.5 \\
\hline \multicolumn{7}{|c|}{ Purity $\%$} \\
\hline $\mathrm{TB}$ & 38.3 & 40.3 & $47.0^{a}$ & $36.0^{b}$ & $41.5^{\mathrm{ab}}$ & $34.9 \mathrm{~b}$ \\
\hline SS & 38.1 & 37.2 & 43.4 & 35.7 & 35.3 & 37.0 \\
\hline GB & 35.8 & 36.1 & 38.5 & 37.5 & 39.3 & 37.5 \\
\hline$S T$ & 32.1 & 36.1 & 40.3 & 32.3 & 30.4 & 33.7 \\
\hline$S M$ & 34.3 & 39.5 & 41.7 & 33.6 & 35.3 & 37.5 \\
\hline LD & 35.8 & 36.2 & 39.6 & 35.3 & 35.2 & 34.3 \\
\hline
\end{tabular}

\section{4) Chemical characteristics}

The heavier animals have a tendency towards more fat and less protein in all muscles considered and significant values were found only for T.B. (Table 6). The fat and protein content of muscles is not affected by feeding levels in respect of the low degree of fatness of the animals. Feeding levels affect subcutaneous and intermuscular fat more than intramuscular fat. 
TABLE 6

CHEMICAL COMPOSITION (SS)

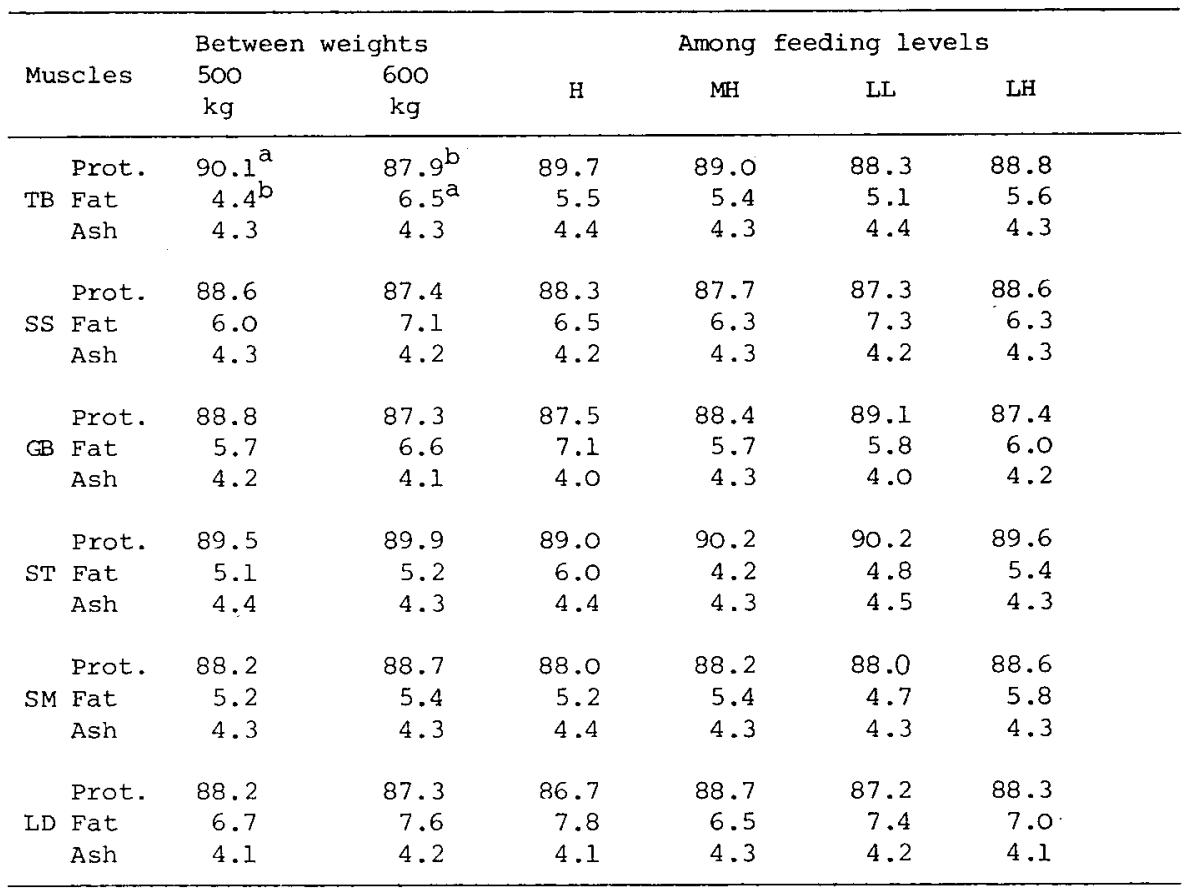

\section{Conclusions}

As the meat characteristics are little influenced by the experimental factors, the genotype can usefully be reared on to heavier weights when considering the high development of musculature and low deposition of fat, intramuscular fat in particular.

The higher feeding cost for the $600 \mathrm{~kg}$ animals due to the variations in maintenance requirements, is compensated by the lower incidence of calf cost per $\mathrm{kg}$ of carcase.

The most suitable feeding level is LH because of the low fat deposition in the gain during the finishing period. The fat deposition in the $\mathrm{H}$ level is not excessive and therefore an extension of the finishing period, after a period of restricted feeding, could be considered advantageous.

\section{References}

Almquist C.N., Brungardt V.H., Tyler W.J., Waldman R.C., 1971 . Growth and efficiency of Holstein steers as influenced by liveweight and energy intake. J. Dairy Sci. 54, 681-687.

ANDERSEN H. REFSGAARD, 1975. The influence of slaughter weight and level of feeding on growth rate, feed conversion and carcass composition of bulls. Beretn. Sta. Husdyrbrugsforsog. Copenhagen. $430 \mathrm{pp}$. 
Beranger C., 1978. Feed efficiency and genotype-nutrition interaction in growing animals particularly in cattle for beef production. In Patterns of growth and development in cattle. Nijhoff-London, 373-391.

Borghese A., Romita A., Gigli S., 1977. Caratteristiche produttive di meticci Frisoni in confronto con la razza pura. I. -Accrescimento e resa macello. Ann. Sper. Zootec. 10, 161-174.

Borghese A., Romita A., Gigli S., 1978a. Caratteristiche produttive di meticci Frisoni in confronto con la razza pura. II. -Valutazione quanti-qualitativa delle carcasse e delle carni. Ann. Ist. Sper. Zootec. 11, 71-91.

Borghese A., Romita A., Gigli S., Mormile M. 1978b. Valutazione delle caratteristiche mioreologiche delle carni bovine mediante Instrom 1140. Atti. Soc. It. Sci. Vet. $32,397$.

Borghese A., Romita A., Gigli S., Di Giacomo A., 1978c. Eating quality of buffalo and bovine calves slaughtered at 20-28 and 36 weeks of age. In Patterns of growth and development in cattle. Nijhoff-London. 603-611.

Bouton P.E., Ford Anne L., Harris P.V., Shorthouse W.R., Ratcliff D., Morgan J.H.L., 1978. Influence of animal age on the tenderness of beef : muscle differences. Meat Sci. 2, 301-311.

Carrol M.A., 1976. The impact of carcass and meat aspects on experimental design, particularly in relation to feeding levels at time of slaughtering. Criteria and methods for assessment of meat characteristics in beef production. CEE, Brussels.

De Boer H., Dumont B.L., Pomeroy R.W., Weniger J.H., 1974. Manual of E.A.A.P. reference methods for the assessment of carcass characteristics. Liv. Prod. Sci. 1, 151-164.

Geay Y., Robelin F., Beranger C., 1976. Influence du niveau alimentaire sur le gain de poids vif et la compositioin de la carcasse de différentes races. Ann. Zootech. 25, 287-298.

GEAY Y., 1977. Interaction entre génotype et nutrition chez les bovins destinés à la production de viande. 28th Annual meeting of E.A.A.P. Brussels, 1977.

GEAY Y., 1978. Dressing percentage in relation to weight, sex and breed. In Patterns of growth and development in cattle. Nijhoff-London, 35-46.

LANGHOLZ H.-J., 1978. Effect of breed and interaction with nutrition. In patterns of growth and development in cattle. Nijhoff-I condon, 461-480.

Prost E., Pelczynska E., Kotula A.W., 1975. Quality characteristics of bovine meat. II Beef tenderness in relation to individual muscles, age and sex of animals and carcass quality grade. J. Anim. Sci. 41, 541-547.

Reagan J.O., Carpenter Z.L., Smith G.C., 1976. Age related traits affecting the tenderness of the bovine longissimus dorsi muscle. J. Anim. Sci. 43, 1198-1205.

Rohr K., Daenicke R., 1978. Influence of nutrition on the growth pattern of fattening bulls of two different breeds (Friesian and Simmental). In Patterns of growth and development in cattle. Nijhoff-London, 413-421.

Sorensen M., LykKeaA J.L., Andersen H.R., 1972. Fodringsin tensitetens indflydelse patilvakst og kodkvalitet hos ungtyre og stude. Arbog Landok. Forsogslab Kobenhavn. 370-376.

Williams D.R., Bergstrom P.L., 1976. Anatomical jointing, tissue separation and weight recording proposed as the EEC standard method for beef. Meat Res. Inst. England. 


\title{
Discussion
}

\author{
Chair : D. LANARI (Italy)
}

Y. GEAY (France), - I would like to ask a question on the paper presented by Dr. Foldager. Two levels of feeding during the last period were compared, 55 per cent and "ad libitum". At the end the same percentage of fat was observed in the carcase. Was there any difference in distribution of this fat ? Dr. Romita pointed out that the level of feeding did not modify the different fat and tissue in the carcase in the same proportions. It would be interesting to know whether it was possible to modify the proportions of external, internal and subcutaneous fat without changing the intramuscular fat.

B. Bech Andersen (Denmark). - We have not distinguished between subcutaneous and internal fat. That is one of the problems. Of course, we know something about the fat thickness and so on, the organ fat and the fat in the muscles. So we can say that the general rules are confirmed in the experiment. I would like to add that you would affect all your fat depots when you decrease the feeding intensity, but there are small variations to this, as one would expect.

Ch. V. BoucQue (Belgium). - I would like to ask a question to our Danish colleagues. You studied carcase quality and meat quality. At the end you refer to 14 per cent fat in the carcase. Was that your objective ? Did you not want to go above that ? Also, what was the relation between the tenderness of the meat and the total fat in the carcase ? The situation will be different from breed to breed and we don't measure the meat tenderness for all the cuts we have, but there is a correlation between the tenderness of the meat and readiness for slaughter. You can have excessive subcutaneous fat, but you need a certain minimum of subcutaneous fat to obtain good tender meat. Have you any objective measurements on that? It may be for your breed.

B. Bech Andersen. - I would just like to say that this 14 per cent, in Foldager's figures, is just one example. It was just to illustrate that it is possible to regulate, by feeding intensity and by weight, the fat percentage you would want to achieve. It is not the optimum fat percentage. We know that you need different fat percentages in $300 \mathrm{~kg}$ young bulls in the market in Italy, and $500 \mathrm{~kg}$ young bulls in other markets. It was only an example.

A. Neimann-Sørensen (Denmark). - We put up 14 per cent as possible goal. I wish Dr. Kousgaard could have been here because he is our meat man. When we take this 14 per cent as a lead it is because when you have this you will have intramuscular fat and this is what the consumer appreciates. You will have 2.5 per cent -3 per cent in the muscles. These two are related, therefore 14 per cent would give you a certain guarantee, though there may be some difference in the sexes.

As Dr. Foldager showed with the different tissues, fat deposition occurs systematically. First, the fat will be deposited in the internal organs; that has the first priority. Then it goes submuscular, then intermuscular, and lastly it will be intramuscular. If you decrease the feeding level, it will be taken away from these various depots in the reverse order. This is how the system works.

J. Robelin (France). - I would like to add one thing. I am not sure if we are all in agreement as to the role of the internal fat. Two or three years ago, Mr. Geay and I had an experiment in which the internal fat was greatly decreased by feeding levels. I can also refer to other studies which are completely different ; work concerning the "in vitro" rate of synthesis of lipids from carbohydrates. This was done in lambs by French colleague, who showed that there was a very high turnover rate of lipids in ruminants in the internal fat, which could be considered to be rather similar to the liver of monogastrics. It seems that, in ruminants, the internal fatty tissues seems to play a role very similar to the liver, and with a very high rate of lipid synthesis. 
H. RefsGaARd ANDERSEn (Denmark). - Dr. Boucqué asked what fat content we wanted. It is rather difficult to say, because we have to slaughter at a constant weight as we export to Italy. When we have Friesians and Red Danish, the animal cannot be overfed

As regards the influence of feeding levels on tenderness, Dr. Foldager showed that there was little difference between f'eeding levels. However, perhaps it is misleading when we measure with a shearforce value. I think we would find a bigger difference with panel tests. In this first experiment we did not have panel tests, but we have in the two last experiments and we expect to find bigger differences, according to feeding levels, than we got when we measured at shearforce value.

M.G. KEANE (Ireland). - In assessing the daily growth rate of the three main tissues, muscle fat and bone, for the different feeding levels, did you find a level at which, for instance, protein or meat or muscle growth was maximised at 70 per cent or 85 per cent, and that a higher feeding level led to no further meat or muscle growth whatsoever - and it was totally fat - or was there some increase in meat growth all the way up to 100 per cent, even if it was at a declining level?

A. NeImann-Sørensen. - There was always a gain of lean ? There was no state where there was no lean deposit? Whatever age, whatever weight or whatever feeding level you had, there was always a deposition of protein?

D. Lanari. - I have a comment to Dr. Romita. To change the feeding level over the last $60 \mathrm{~kg}$ is a very short period. I think it would be better to increase this time interval.

A. Romita (Italy). - Yes I agree, and in conclusion I think it would be interesting to prolong the progression of the period of fattening.

A.J.H. VAN Es (The Netherlands). — I an always a little puzzled when the term "tenderness of meat" comes up. Am I right in saying that the older the muscle, the less tender it is, the higher the intermuscular fat content of that muscle, the more tender it is, and the longer you cook your muscle, the more tender it becomes? Is this true, or are there many other factors? The way you treat your carcase temperature, and the length of the lower temperature, is another factor. Is it possible for technology to handle all kinds of meat in a sufficient way that it always becomes tender ? Can the consumer always handle the meat in such a way that it doesn't matter what kind of meat we produce?

A. Neimann-Sørensen. - If we talk about toughness instead of tenderness, we have two reasons for toughness. One relates to the muscles fibres, and the other one is connected with deposition of connective tissue. The connective tissue toughness cannot be handled technologically at this moment. You have to infuse some enzymes, or something like that, and is not allowed in our country. This toughness occurs when the animal gets old and cannot be cured by technology. The other kind of toughness, relating to the muscles : the hanging time, and the temperature of the hanging time, will cure many of these things.

\section{A.J.H. VAN Es. - And cooking ?}

A. Neimann-Sфrensen. - You can cook anything until it falls apart, but then you may have a taste problem.

C. Beranger (France). - No-one has mentioned the problem of a short period of a different level of feeding which can change the body composition, especially where fat content is concerned. There are a few experiments in this area which show that, even at a high level of feeding and high liveweight, you can decrease the percentage of fat by a short period of decreasing the level of feeding. But there is little work in this area in terms of feed conversion and the cost of this period, in which we have to fatten animals without gain, or with very slow gain, the cost is very high. Is this important or not? More work could be done on it.

H. Bickel (Switzerland). - May I ask a question ? I am not familiar with these figures on tenderness. With the Instrom device, the higher value means less tenderness? But with the panel, the higher value means higher tenderness? Am I right ? I just wanted to clarify this.

A. Neimann-Sørensen. - Yes. 